\title{
Original article (short paper) \\ The period of the day affects the twenty-four hour blood pressure response to an acute combined exercise session in Brazilian jiu jitsu athletes
}

\author{
Rafaello Pinheiro Mazzoccante \\ Ioranny Raquel Castro de Sousa \\ Universidade Católica de Brasília, Brazil \\ Sérgio Rodrigues Moreira \\ Universidade do Vale do São Francisco, Petrolina, Brazil \\ Jonato Prestes \\ Herbert Gustavo Simões \\ Carmen Sílvia Grubert Campbell \\ Universidade Católica de Brasília, Brazil
}

\begin{abstract}
The purpose of this study was to compare the effect of a combined exercise session performed at different periods of the day on the $24 \mathrm{~h}$ blood pressure (BP) response. Anaerobic threshold (AT) and 12 repetition maximum $(12 \mathrm{RM})$ tests were evaluated in nine Brazilian jiu-jitsu athletes (male) $(22 \pm 3.7 \mathrm{y} ; 176 \pm 5.0 \mathrm{~cm} ; 73.4 \pm 9.7 \mathrm{~kg} ; 6.8 \pm 2.1$ $\%$ body fat). Four experimental sessions were performed: resistance exercise followed by aerobic exercise [Morning (MornS) and Afternoon (AfternS)] and Control (C) [Morning and Afternoon]. The morning sessions were conducted at 09:00 a.m. and the afternoon sessions were conducted at 3:00 p.m. The resistance exercise consisted of three sets at 90\% of a 12RM for six resistance exercises. The aerobic exercise consisted of $15 \mathrm{~min}$ at $90 \%$ of the AT. Blood pressure (BP) was measured before, during and $1 \mathrm{~h}\left(\right.$ Microlife $\left.{ }^{\circledR} B P 3 A 1 C\right)$ after the performance of exercises in laboratory, and then during daily activities for the succeeding $23 \mathrm{~h}$ by ambulatory BP monitoring (Dyna-MAPA $\left.{ }^{\circledR}\right)$. Analysis of the area under the curve (AUC) indicated significant reductions in blood pressure parameters at various time points during the $24 \mathrm{~h}$ monitoring period. For systolic BP (SBP), significantly lower values were shown following the morning session versus the control (MornS: $1756.2 \pm 100.8$ vs. C: $1818.2 \pm 84.3 \mathrm{mmHg} * 15 \mathrm{~h} ; p<.05$ ) and total-24h (MornS: $2695.8 \pm 143.3$ vs. C: $2784.1 \pm 143.2 \mathrm{mmHg} * 24 \mathrm{~h} ; p<.05$ ). The total-24h mean BP (MAP) was also significantly lower following the morning session versus the control (MornS: $2015.7 \pm 121.2$ vs. C: $2087.3 \pm 153.8 \mathrm{mmHg} * 24 \mathrm{~h} ; p<.05$ ). There were significant differences in the sleeping AUC of SBP (AfternS: $883.6 \pm 27.0 v s$. C: $965.2 \pm 67.9 \mathrm{mmHg} * 9 \mathrm{~h} ; p<.05$ ), diastolic BP(DBP) (AfternS: $481.4 \pm 30.9 v s$. MornS: $552.9 \pm 34.2$ and C: $562.1 \pm 52.3 \mathrm{mmHg} * 9 \mathrm{~h} ; p<.01$ ) and MBP (AfternS: $651.9 \pm 22.4 v s$. MornS: $708.7 \pm 43.1$ and C: $726.9 \pm 64.7 \mathrm{mmHg} * 9 \mathrm{~h} ; p<.01)$. The combined exercise performed at different periods of the day contributed distinctly to the reduction of BP. The morning session was important in reducing SBP and MBP in the total-24h monitoring, while the afternoon session reduced SBP, DBP and MBP during sleeping in jiu-Jitsu athletes.
\end{abstract}

Keywords: combined exercise, hypotension, cardiovascular response

Resumo - "O período do dia afeta a resposta de pressão arterial de 24 horas para uma sessão aguda de exercício combinado no brasileiro de jiu jitsu atletas." O objetivo deste estudo foi comparar o efeito de uma sessão combinada de exercício realizada em diferentes períodos do dia, sobre as respostas de pressão arterial (PA) durante 24h. Limiar anaeróbio (LA) e

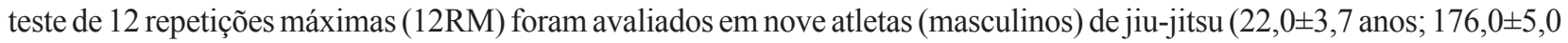
$\mathrm{cm} ; 73,4 \pm 9,7 \mathrm{~kg} ; 6,8 \pm 2,1 \%$ gordura). Quatro sessões experimentais foram realizadas: exercício resistido + exercício aeróbio [manhã (ManhaE) e tarde (TardeE)] e sessão controle (C) [manhã e tarde]. A sessão da manhã foi realizada 09:00h e a sessão da tarde foi realizada ás 15:00h. O exercício resistido consistiu em três séries a 90\% de 12RM em seis exercícios. O exercício aeróbio consistiu em $15 \mathrm{~min}$ a $90 \%$ do LA. PA foi mensurada antes, durante e 1 h (Microlife ${ }^{\circledR}$ BP3AlC) após a realização dos exercícios em laboratório e $23 \mathrm{~h}$ durante as atividades diárias com a monitorização ambulatorial da PA (Dyna-MAPA ${ }^{\circledR}$ ). Ao analisar os valores da área abaixo da curva (AAC) indicaram reduções significativas nos parâmetros de pressão arterial em vários pontos de tempo durante o período de acompanhamento de 24 horas. Para a PA sistólica (PAS), observaram-se valores significativamente mais baixos após a sessão realizada pela manha em comparação a sessão controle na vigília (ManhaE: 1756,2 $\pm 100,8$ vs. C: $1818,2 \pm 84,3 \mathrm{mmHg} * 15 \mathrm{~h} ; p<0,05$ ) e 24h-total (ManhaE: 2695,8 $\pm 143,3$ vs. C: $2784,1 \pm 143,2 \mathrm{mmHg} * 24 \mathrm{~h} ; p<0,05$ ). Nas $24 \mathrm{~h}$-total também ocorreu diferença na PA média (PAM) (ManhaE: $2015,7 \pm 121,2$ vs. C: $2087,3 \pm 153,8 \mathrm{mmHg} * 24 \mathrm{~h} ; p<0,05)$. Houve uma diferença significativa na AAC no período de 


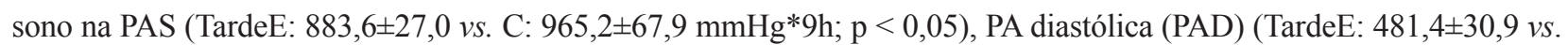
ManhaE: 552,9 $\pm 34,2$ e C: $562,1 \pm 52,3$ mmHg*9h; $p<0,01$ ) e PAM (TardeE: 651,9 $\pm 22,4$ vs. ManhaE: 708,7 $\pm 43,1$ e C: $726,9 \pm 64,7 \mathrm{mmHg} * 9 \mathrm{~h} ; p<0,01)$. O exercício combinado realizado em diferentes períodos do dia contribuiu distintamente na redução da PA. A sessão ManhaE foi importante na redução da PAS e PAM nas 24h totais de monitorização e a sessão TardeE mais importante na redução da PAS, PAD e PAM no sono de atletas de jiu-jitsu.

Palavras-chave: exercício combinado, hipotensão, resposta cardiovascular

Resumen - "La hora del día afecta la respuesta de la presión arterial de 12:0 am para una sesión de ejercicio combinado aguda en deportistas de Jiu-Jitsu brasileño." El objetivo de estudio fue comparar el efecto de una sesión combinada de ejercicio realizada en diferentes períodos del día, sobre las respuestas de presión arterial (PA) durante 24h. Umbral anaeróbico (Uan) y test de 12 repeticiones máximas (12RM). Fueron evaluados nueve atletas (hombres) de jiu-jitsu (22,0 $\pm 3,7$ años; $176,0 \pm 5,0 \mathrm{~cm} ; 73,4 \pm 9,7 \mathrm{~kg} ; 6,8 \pm 2,1 \%$ grasa). Cuatro sesiones de test fueron realizadas: ejercicio resistido + ejercicio aeróbico [mañana (MañaE) y tarde (tardE)] y sesión control (C) [mañana y tarde]. La sesión matinal ocurrió las 9.00 y la sesión vespertina ocurrió las 15.00 . El ejercicios resistidos consistió en tres series a $90 \%$ de 12 RM em seis ejercicios. El ejercicio aeróbico consistió en 15 minutos a 90\% de LA. La presión arterial (PA) fue medida antes, durante y 1 hora tras la realización de los ejercicios en laboratorio (Microlife ${ }^{\circledR}$ BP3A1C) y 23 horas durante las actividades diarias con el monitoreo ambulatorio de la PA (Dyna-MAPA $\left.{ }^{\circledR}\right)$. Mediante el análisis del área bajo la curva $(A B C)$ mostraron reducciones significativas en los parámetros de PA en varios puntos de tiempo durante el período de seguimiento de 24 horas. Para la PA sistólica (PAS), hubo valores significativamente más bajos después de las sesiones de vigilia (MañaE: $1756,2 \pm 100,8$ vs. C: $1818,2 \pm 84,3$ mmHg*15h; $p<0,05)$ y 24hs-total (MañaE: $2695,8 \pm 143,3$ vs. C: $2784,1 \pm 143,2$ mmHg*24h; $p<0,05)$. En las 24hs-total también ocurrió diferencia en la PA media (PAM) (MañaE: 2015,7 $\pm 121,2 v s$. C: $2087,3 \pm 153,8 \mathrm{mmHg} * 24 \mathrm{~h} ; p<0,05)$. En durante el sueño ocurrieron alteraciones en el ABC de la PA PAS (tardE:

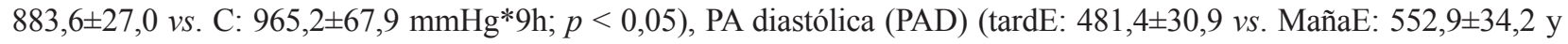
C: $562,1 \pm 52,3 \mathrm{mmHg} * 9 \mathrm{~h} ; p<0,01$ ) y PA media (tardE: 651,9 $\pm 22,4$ vs. RAM: 708,7 $\pm 43,1$ y C: $726,9 \pm 64,7 \mathrm{mmHg} * 9 \mathrm{~h} ; p$ $<0,01)$. El ejercicio combinado realizado en diferentes períodos del día, contribuyó de modo distinto en la reducción de la PA, donde la sesión MañaE fue importante en la reducción de la PAS y PAM en las 24 horas totales de monitoreo y la sesión tardE más importante en la reducción de la PAS, PAD y PAM en el sueño de los atletas de jiu-jitsu.

Palabras claves: ejercicio combinado, hipotensión, respuesta cardiovascular

\section{Introduction}

The risk for developing high blood pressure (BP) (hypertension) can be associated with factors such as smoking, unhealthy diet and physical inactivity (Brazilian Society of Hypertension, 2010), as well as the daily occupations, such as exposure to high stress levels during work activities (Ribeiro et al., 2011).

Jiu-jitsu is characterized by intense body contact between athletes and the main techniques involve the immobilization of the opponent; such as projections, immobilizations, clamping, chokes and twists (Andreato et al., 2014). These variations pose a high intensity and demanding exercise challenge, executed under high force isometric muscle actions. Scarpi et al. (2009) verified an abrupt increase in intra-ocular BP when the athlete was exposed to a choke / immobilization due to the constant use if isometric force, inducing a raise of $\mathrm{BP}$ values during the fight (Andreato et al., 2014; Anthony, Baross, Wiles, \& Swaine, 2012).

Moreover, jiu-jitsu athletes may also be subjected to high levels of stress. Moreira et al. (2012) observed higher cortisol concentrations following a competitive fight as compared with a fight during training, highlighting the high psychological stress on the athletes during a competition. The increase in the cortisol release and psychological stress can directly affect BP values. It has been shown that this cardiovascular reactivity occurs not only during competitions, but also during the athlete's training routine (Andreato et al., 2014).

The period of the day should be also considered in the evaluation of cardiovascular behavior. For example, there is a variation of BP reactivity throughout the day, which is higher during the morning period as compared with the afternoon period (Jones et al., 2006).

Clinical and epidemiological studies have confirmed the benefits of exercise on cardiovascular health (Queiroz, Kanegusuku, \& Forjaz, 2010; Medina, Lobo, Souza, Kanegusuku, \& Forjaz, 2010). Exercise has been widely recommended for the acute decrease and/or controlling of BP. A single bout of aerobic or resistance exercise can acutely reduce BP below pre-exercise values in elderly women (Santana et al., 2013), diabetic (Morais et al., 2011, Motta et al., 2010; Sales et al., 2012; Simões, Moreira, Kusuhmick, Simões, \& Campbell, 2010), hypertensive (Moraes et al., 2007), overweight/obese (Tibana, Pereira, Navalta, Bottaro, \& Prestes, 2013) and normotensive individuals (Rezk, Marrache, Tinucci, Mion, \& Forjaz, 2006); a phenomena known as post-exercise hypotension (PEH). Hecksteden, Grutters and Meyer (2013) reported that the magnitude of PEH is related with the training-induced decrease of BP following a walking/running program (45 minutes, four times per week at $60 \%$ heart rate reserve) during four weeks in healthy untrained subjects aged 30 to 60 years. 
Although combined aerobic and resistance exercise has been widely used in the daily practice, there is no consensus regarding the effects of this strategy during different periods of the day on the $24 \mathrm{~h}$ $\mathrm{BP}$ response. Most studies investigated BP response up to 60-120 minutes following exercise (Kesse, Farinatti, Pescatello, Cunha, \& Monteiro, 2012; Kesse, Farinatti, Pescatello, \& Monteiro, 2011; Motta et al., 2010; Rezk et al., 2006; Santana et al., 2013; Simões et al., 2010), which limits the information to longer periods following exercise. This analysis would be very important, considering the cardiovascular risks elicited during the morning and afternoon, such as the increased occurrence of stroke. Elevated BP is considered to be an important inducible factor of stroke due to the rupture of vulnerable atheromatous plaques, resulting in occlusive thrombus (Jones et al., 2006; Stergiou et al., 2002).

Thus, the aim of the present study was to compare the effect an acute combined exercise session performed at different periods of the day on the $24 \mathrm{~h}$ BP response in jiu-jitsu atheletes. We hypothesized that the combined exercise in both periods protocols would induce PHE, but at different moments of the day.

\section{Methods}

\section{Subjetcs}

This study was approved by the local Human Research Ethics Committee of the Catholic University of Brasilia (Protocol No. 126/10). The sample size calculation was performed using the $G^{*}$ Power 3.1 software. When considering the effect size $=.57 ; \alpha=5 \%$; power $=.95$ and the correlation between repeated measures of $r=.5$, the sample size required for the proposed objectives was nine participants. Subsequently, nine male young adults $(22.0 \pm 3.7 \mathrm{y} ; 73.3 \pm 9.7$ $\mathrm{kg} ; 176.0 \pm 5.0 \mathrm{~cm} ; 6.8 \pm 2.1 \%$ body fat) signed a written consent form and volunteered to participate in this study. All subjects were jiu-jitsu athletes with regional and PanAmerican results, who trained at least three to five times per week at the same period of the day with a minimal experience of one year (Table 1).

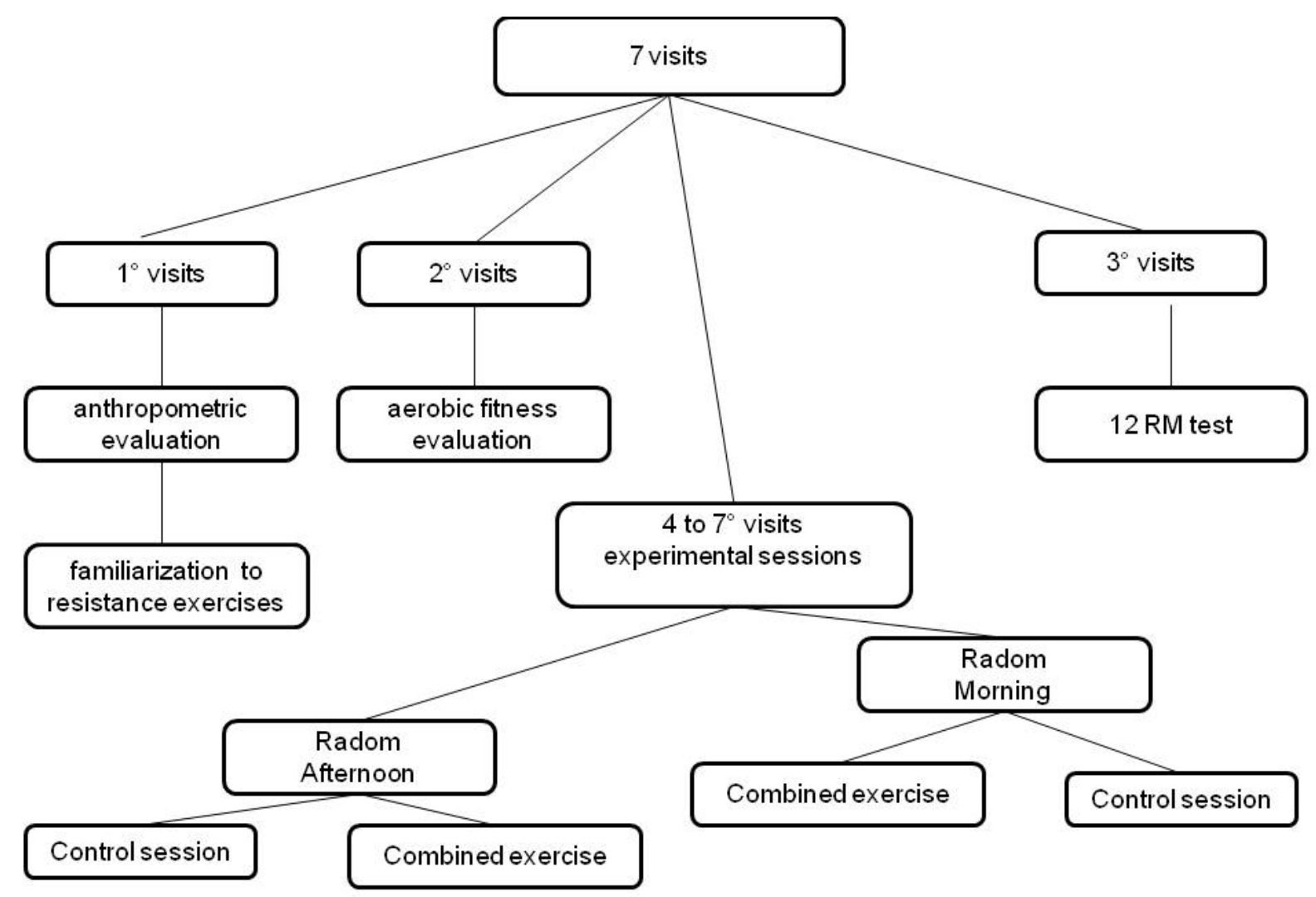

Figure 1. Flowchart of the study. RM = repetition maximum.

\section{General procedures}

Before the experimental sessions all volunteers were submitted to an electrocardiogram in order to verify if they were apt to participate in the study. The exams were performed by a cardiologist at the Physical Evaluation and Training Laboratory of the Catholic
University of Brasília. The exclusion criteria adopted were: any cardiovascular impairment that would compromise performing the experimental sessions; any kind of bone or muscle injury; and presence of hypertension (systolic blood pressure at rest higher than $140 \mathrm{mmHg}$ and diastolic blood pressure at rest higher than $90 \mathrm{mmHg}$ ), heart disease or other cardiovascular commitment. 
Each subject performed a total of seven trials, on separate days, as follows: 1st visit - anthropometric measurements (Jackson \& Pollock, 1978; Siri, 1961) and familiarization on resistance exercise equipment and 12 repetition maximum (12RM) testing; 2nd visit - aerobic fitness evaluation; 3rd visit - 12RMs re-test; and then the 4th, 5th, 6th and 7 th visits - experimental sessions performing resistance exercise (RE) followed by aerobic exercise (AE) in different periods of the day (morning and afternoon), the experimental sessions had a minimum interval between sessions 48 hours. Volunteers were instructed to refrain from physical exercise, and not to change their daily diet $24 \mathrm{~h}$ before the experimental sessions.

\section{Assessment of aerobic fitness}

The participants were instructed to run $1,600 \mathrm{~m}$ or four times around a $400 \mathrm{~m}$ track in the lowest possible time. The mean velocity was calculated (mV1600) by dividing the distance by the time in which they completed the test. In order to characterize the sample, maximal oxygen uptake $\left(\mathrm{VO}_{2} \max \right)$ was calculated using the equation proposed by Almeida et al. $2010\left[\mathrm{VO}_{2} \max =\right.$ $\left.(0.177 * 1600 \mathrm{mV})+8.101 ; R^{2}=.89\right]$. To determine the intensity of the aerobic exercise during the combined exercise session, the maximal blood lactate steady-state intensity was determined (anaerobic threshold - AT) by lactate minimum (LM) test using the equation proposed by Sotero, Pardono, Campbell and Simões (2009) $\left[\mathrm{LM}=(0.7507 * 1600 \mathrm{mV})+21.575 ; R^{2}=.96\right]$.

\section{Strength assessment (12RM)}

Before 12RM testing, subjects were familiarized with the resistance exercises, which consisted of the following: leg press, chest press, leg extension, front lat pull-down, leg curl and seated row. Four attempts interspersed by 3-5 minutes intervals were allowed in each exercise until the 12RM load was determined. The 12RM testing was conducted in the same order that exercises were executed as part of the experimental protocol.

\section{Aerobic exercise (AE)}

AE sessions were performed on a treadmill (Movement ${ }^{\circledR}$, Sao Paulo, Brazil) with an intensity corresponding to $90 \%$ of the AT during 15 minutes.

\section{Resistance exercise (RE)}

The RE sessions consisted of a circuit approach, alternating between the upper and lower body exercises at $90 \%$ of the 12RM. Subjects completed three sets of 12 repetitions for each of the six exercises (Righetto, Powertec, São Paulo, Brazil) in the same order mentioned above. The rest interval between exercises and circuits was 10 seconds (time required to equipment change). Each muscle contraction lasted 4 s (accounting for the eccentric and concentric phases of the movement). The RE sessions lasted about 15 minutes.

\section{Experimental sessions of combined exercise}

All experiments sessions were completed in the laboratory under controlled temperature of $\sim 20^{\circ} \mathrm{C}$ and relative air humidity between 50 and 70\% (Guimarães et al., 2003). Four experimental sessions were completed, two control sessions (C) and two exercise sessions at the morning (9 a.m. - MornS) and afternonn (3 p.m. - AfternS). The combined exercise sessions consisted of 15 minutes of RE followed by 15 minutes of AE. Control sessions were completed during the same period of the day during which subjects remained in a seated position for 30 minutes. During the morning control session, BP was monitored only for $1 \mathrm{~h}$.

\section{Blood pressure measurement}

Systolic (SBP), diastolic (DBP) and mean arterial pressure (MAP) were measured before, during and after exercise and control sessions. Pre-exercise measures of BP were completed with the subject seated quietly during 5, 10 and 15 minutes. The mean of the three measures was considered the pre-exercise BP. Post-exercise measures were performed every 15 minutes during 60 minutes at the seated position. Laboratory measures were taken by a digital oscilometric device Microlife $\AA$ mod. BP3A1C.

After the above-mentioned 60 minutes, subjects were instructed to perform their personal hygiene in a time interval of 20 minutes, and prepare themselves to use the ambulatory BP monitor (Dyna-MAPA $\AA)$, in accordance with the manufacturer's instructions. The ambulatory BP measurements were taken during a period of $23 \mathrm{~h}$, one hour after the measurement taken in the laboratory facilities, totaling $24 \mathrm{~h}$ of BP measurements taken. SBP, DBP and MAP were measured every 15 minutes during the awake period (15h) and every 30 minutes during the sleep period (9h). These measurements were considered valid when $90 \%$ of all measurements were recorded.

\section{Measurement of heart rate (HR) and rating of perceived exertion (RPE)}

During AE sessions the RPE was evaluated by 15 points Borg scale [6 to 20] (Borg, 2000). The RPE during RE was determined by OMNI-RES scale [0 to 10] (Rodrigues et al., 2010; Delpenho, 2009). HR was also monitored during exercise sessions (Polar, RS-800-CX, Finland).

\section{Statistical analysis}

Data are presented as means and standard deviation of the mean. The normalcy of the data was checked by the 
Shapiro-Wilk test. Sphericity was verified by Mauchly test or épsilon de Greenhouse-Geisser when necessary. For the comparison between the different periods for RPE, number of repetitions, running speed and HR, paired student $t$-tests were used. The area under the curve (AUC) was adopted for the mathematical calculation of $\mathrm{BP}$ variables, used by dividing the post-exercise period into 4 moments (time 1, time 2, time 3 and time 4$)$ and summing the values as indicated in the formula. $\mathrm{AUC}_{(\mathrm{mmHg} \text { min })}=\left(\mathrm{m}_{0}+\mathrm{m}_{1}\right) \cdot \mathrm{t}_{1} / 2+\left(\mathrm{m}_{1}+\mathrm{m}_{2}\right) \cdot \mathrm{t}_{2} / 2+\left(\mathrm{m}_{2}+\mathrm{m}_{3}\right) \cdot \mathrm{t}_{3} / 2+$ $\left(\mathrm{m}_{3}+\mathrm{m}_{4}\right) \cdot \mathrm{t}_{4} / 2$. Repeated measures ANOVA (comparison intra and inter sessions), with post-hoc of Bonferroni was used for the BP measures during time. Cohen's $d$ was calculated to show the effect size. Significance level was fixed at $p \leq .05$ and SPSS software v. 20 was adopted.

\section{Results}

Table 1 presents the subjects characteristics.

Table 1. Subjects characteristics $(n=9)$.

\begin{tabular}{lc}
\hline Variables & Mean \pm SD \\
\hline Age $(\mathrm{y})$ & $22.0 \pm 3.7$ \\
Body mass $(\mathrm{kg})$ & $73.4 \pm 9.7$ \\
Height $(\mathrm{cm})$ & $176.0 \pm 5.0$ \\
Body mass index $\left(\mathrm{kg} \cdot \mathrm{m}^{2}(-1)\right)$ & $23.0 \pm 1.5$ \\
Body fat $(\%)$ & $6.8 \pm 2.1$ \\
VO $_{2}$ max $\left(\mathrm{mL} \cdot \mathrm{kg}^{-1} \cdot \mathrm{min}^{-1}\right)$ & $50.4 \pm 4.0$ \\
Anaerobic threshold $\left(\mathrm{km} \cdot \mathrm{h}^{-1}\right)$ & $12.4 \pm 1.3$ \\
\hline
\end{tabular}

$\mathrm{VO}_{2}$ max: Maximum oxygen consuption.
Results from HR, RPE, running speed, number of repetitions and post-exercise BP are presented in Table 2. There were no statistically significant differences between exercise sessions completed during the morning and afternoon $(p>.05)$. Conversely, both of the RE session (AfternS and MornS) showed high values for SBP and MAP versus their respective control sessions $(p<.05)$. However, DBP showed high values in both control sessions versus $\operatorname{RE}(p<.05)$.

Moreover, to observe the SBP and MAP were higher of the experimental sessions versus control in respective moment post-RE $(p<.05)$, however, only DBP showed a significant difference between the two sessions to control when post-RE AfternS session $(p>.05)$ (Table 2).

The values related to control session in the morning and afternoon are shown in Table 2. These results did not differ significantly at rest or at any time during the recovery (R15-R60), highlighted by the AUC.

Table 3 presents the values of SBP, DBP and MAP at the different periods of $24 \mathrm{~h}$ (Sleep, Awake and total 24h). A significant difference was found in the MornS session versus the control session during the awake period $(p<.05)$. Although the experimental session was not significantly different as compared with the control for SBP, DBP, and MAP during the total $24 \mathrm{~h}$ period, the effect sizes (Cohen $d$ ) were high to moderate (Table 3 ).

Table 4 presents the AUC values of BP. There was a significant decrease in SBP in the MornS as compared with $\mathrm{C}$ session during sleeping and $24 \mathrm{~h}$ period $(p<.05)$. Systolic BP was also decreased in the AfternS versus the $\mathrm{C}$ session during sleeping hours $(p<.05)$. DBP and MAP were lower following the AfternS versus the $C$ and MornS during sleeping hours $(p<.05)$. Twenty-four hour MAP was decreased following the AfternS versus the $\mathrm{C}$ session $(p<.05)$.

Table 2. Physiological response during combined exercise sessions and control $(n=9)$.

\begin{tabular}{|c|c|c|c|c|c|c|}
\hline & & & AfternS & MornS & CAftern & CMorn \\
\hline & \multicolumn{2}{|c|}{ RPE (Borg) } & $14 \pm 2$ & $13 \pm 3$ & - & - \\
\hline $\begin{array}{l}\text { Aerobic exercise } \\
(A F)\end{array}$ & \multicolumn{2}{|c|}{ HR (bpm) } & $179 \pm 9$ & $180 \pm 16$ & - & - \\
\hline & \multicolumn{2}{|c|}{ Speed $\left(\mathrm{km} \cdot \mathrm{h}^{-1}\right)$} & $11 \pm 2$ & $11 \pm 1$ & - & - \\
\hline \multirow{2}{*}{ Resistance exercise (RE) } & \multicolumn{2}{|c|}{ RPE (OMNI) } & $6 \pm 1$ & $6 \pm 2$ & - & - \\
\hline & \multicolumn{2}{|c|}{ Repetitions } & $12 \pm 0$ & $12 \pm 0$ & - & - \\
\hline SBP & \multicolumn{2}{|c|}{ Post-RE } & $153 \pm 12 * *$ & $143 \pm 12 * *$ & $119 \pm 8$ & $115 \pm 3$ \\
\hline$(\mathrm{mmHg})$ & \multicolumn{2}{|c|}{ Post-AE } & $149 \pm 23$ & $142 \pm 17$ & $116 \pm 9$ & $118 \pm 5$ \\
\hline DBP & \multicolumn{2}{|c|}{ Post-RE } & $81 \pm 8^{*}$ & $81 \pm 9$ & $68 \pm 6$ & $69 \pm 6$ \\
\hline$(\mathrm{mmHg})$ & \multicolumn{2}{|c|}{ Post-AE } & $76 \pm 20$ & $77 \pm 7$ & $69 \pm 7$ & $72 \pm 8$ \\
\hline MBP & \multicolumn{2}{|c|}{ Post-RE } & $105 \pm 9 * *$ & $101 \pm 10^{*}$ & $87 \pm 10$ & $84 \pm 4$ \\
\hline$(\mathrm{mmHg})$ & \multicolumn{2}{|c|}{ Post-AE } & $100 \pm 19 ¥$ & $97 \pm 6^{*}$ & $85 \pm 7$ & $88 \pm 7$ \\
\hline \multirow{2}{*}{ Moments / BP control } & \multicolumn{2}{|c|}{ SBP $(\mathrm{mmHg})$} & \multicolumn{2}{|c|}{ DBP (mmHg) } & \multicolumn{2}{|c|}{ MAP (mmHg) } \\
\hline & Caftern & Cmorn & Caftern & Cmorn & Caftern & Cmorn \\
\hline REP & $115 \pm 9$ & $117 \pm 3$ & $69 \pm 8$ & $69 \pm 4$ & $85 \pm 8$ & $85 \pm 3$ \\
\hline $\mathrm{R} 15 \mathrm{~min}$ & $114 \pm 8$ & $116 \pm 8$ & $71 \pm 11$ & $69 \pm 7$ & $85 \pm 9$ & $85 \pm 6$ \\
\hline $\mathrm{R} 30 \mathrm{~min}$ & $112 \pm 8$ & $117 \pm 6$ & $69 \pm 8$ & $71 \pm 6$ & $83 \pm 7$ & $86 \pm 5$ \\
\hline $\mathrm{R} 45 \mathrm{~min}$ & $115 \pm 10$ & $119 \pm 4$ & $66 \pm 7$ & $69 \pm 6$ & $82 \pm 8$ & $86 \pm 4$ \\
\hline R60min & $113 \pm 5$ & $117 \pm 5$ & $71 \pm 9$ & $72 \pm 5$ & $85 \pm 7$ & $87 \pm 5$ \\
\hline AUC & $6963 \pm 444$ & $7185 \pm 205$ & $4326 \pm 472$ & $4329 \pm 335$ & $5162 \pm 408$ & $5248 \pm 265$ \\
\hline
\end{tabular}

$\mathrm{SBP}=$ systolic blood pressure; $\mathrm{DBP}=$ diastolic blood pressure; $\mathrm{MAP}=$ mean arterial pressure; AUC = Area under the curve; Post-RE: Immediately post the first exercise of the session; Post-AE: Immediately post AE session; AfternS: Combined exercise session at the afternoon; MornS: Combined exercise session at the morning; $\mathrm{C}$ : control session. ${ }^{*} p<.05$ as compared with $\mathrm{C}$; $* * p<.001$ as compared with $\mathrm{C} ; ¥ p<.05$ as compared with $\mathrm{C}$ during the afternoon. 
Table 3. Ambulatory blood pressure monitoring results during total-24h awake and sleep moments after different periods of the day of the combined exercise $(n=9)$.

\begin{tabular}{|c|c|c|c|c|}
\hline & & AfternS & MornS & $\mathrm{C}$ \\
\hline \multirow{4}{*}{$\begin{array}{c}\text { SBP } \\
(\mathrm{mmHg})\end{array}$} & Resting & $118 \pm 7$ & $117 \pm 8$ & $117 \pm 6$ \\
\hline & $24 \mathrm{~h}$ & $109 \pm 4^{\#}$ & $109 \pm 5^{\#}$ & $112 \pm 6$ \\
\hline & Awake & $111 \pm 5^{\#}$ & $110 \pm 5^{* \dagger}$ & $115 \pm 7$ \\
\hline & Sleep & $107 \pm 3$ & $105 \pm 6$ & $106 \pm 4$ \\
\hline \multirow{4}{*}{ DBP (mmHg) } & Resting & $68 \pm 5$ & $69 \pm 7$ & $71 \pm 4$ \\
\hline & $24 \mathrm{~h}$ & $61 \pm 4^{\#}$ & $62 \pm 4$ & $64 \pm 6$ \\
\hline & Awake & $63 \pm 5^{\#}$ & $65 \pm 5$ & $66 \pm 7$ \\
\hline & Sleep & $57 \pm 4^{\dagger}$ & $58 \pm 4^{\#}$ & $61 \pm 5$ \\
\hline \multirow{4}{*}{ MAP (mmHg) } & Resting & $82 \pm 6$ & $84 \pm 7$ & $84 \pm 11$ \\
\hline & $24 \mathrm{~h}$ & $82 \pm 4$ & $81 \pm 5^{\#}$ & $84 \pm 6$ \\
\hline & Awake & $83 \pm 5$ & $83 \pm 5$ & $86 \pm 8$ \\
\hline & Sleep & $79 \pm 2$ & $77 \pm 5$ & $78 \pm 5$ \\
\hline
\end{tabular}

$\mathrm{SBP}=$ systolic blood pressure; $\mathrm{DBP}=$ diastolic blood pressure; MAP = mean arterial pressure; AfternS: Combined exercise session at the afternoon; MornS: Combined exercise session at the morning; $\mathrm{C}$ : control session. ${ }^{*} p<.05$ as compared with C. difference in magnitude of effect as compared with the same period of the control session (\#: Cohen's $d=-.49$ to .66 and $\dagger:-.82$ to .88 ).

Tabela 4. Ambulatory blood pressure measurement area under the curve during total $24 \mathrm{~h}$ awake and sleep periods after different periods of the day of the combined exercise $(n=9)$.

\begin{tabular}{ccccc}
\hline & & $\begin{array}{c}24 \mathrm{~h} \\
\left(\mathrm{mmHg}^{*} 24 \mathrm{~h}\right)\end{array}$ & $\begin{array}{c}\text { Awake } \\
\left(\mathrm{mmHg}^{*} 15 \mathrm{~h}\right)\end{array}$ & $\begin{array}{c}\text { Sleep } \\
\left(\mathrm{mmHg}^{*} 9 \mathrm{~h}\right)\end{array}$ \\
\hline & AfternS & $2723.7 \pm 99.0$ & $1840.1 \pm 81.7$ & $883.6 \pm 27.0^{*}$ \\
$93 P$ & MornS & $2695.8 \pm 143.3^{*}$ & $1756.2 \pm 100.8^{*}$ & $939.6 \pm 60.7$ \\
& $\mathrm{C}$ & $2784.1 \pm 143.2$ & $1818.2 \pm 84.3$ & $965.2 \pm 67.9$ \\
\hline & AfternS & $1529.7 \pm 96.8$ & $1048.3 \pm 72.6$ & $481.4 \pm 30.9^{* * \#}$ \\
& MornS & $1565.0 \pm 107.7$ & $1012.2 \pm 77.4$ & $552.9 \pm 34.2$ \\
& $\mathrm{C}$ & $1617.5 \pm 146.7$ & $1055.4 \pm 103.8$ & $562.1 \pm 52.3$ \\
\hline & AfternS & $2022.7 \pm 98.1$ & $1370.8 \pm 79.6$ & $651.9 \pm 22.4^{* * \#}$ \\
& MornS & $2015.7 \pm 121.2^{*}$ & $1307.0 \pm 86.3$ & $708.7 \pm 43.1$ \\
& $\mathrm{C}$ & $2087.3 \pm 153.8$ & $1360.3 \pm 94.9$ & $726.9 \pm 64.7$ \\
\hline
\end{tabular}

$\mathrm{SBP}=$ systolic blood pressure; $\mathrm{DBP}=$ diastolic blood pressure; $\mathrm{MAP}=$ mean arterial pressure; AfternS: Combined exercise session at the afternoon; MornS: Combined exercise session at the morning; $\mathrm{C}$ : control session. ${ }^{*} p<.05$ as compared with $\mathrm{C} ;{ }^{* *} p<.01$ as compared with $\mathrm{C}$; $\# p<.001$ as compared with $\mathrm{C}$ and MornS.

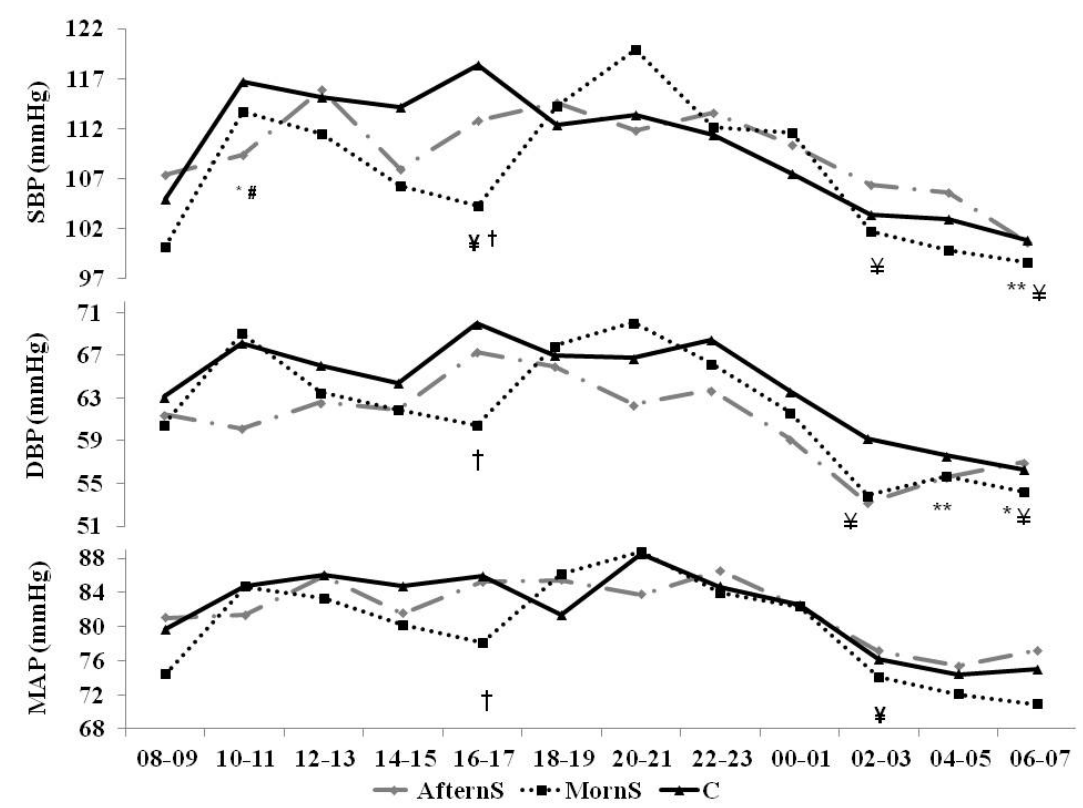

Figure 2. Ambulatory blood pressure monitoring results during $24 \mathrm{~h}$ periods in all experimental sessions after different periods of the day of the combined exercise $(n=9)$. SBP = systolic blood pressure; DBP = diastolic blood pressure; MAP = mean arterial pressure; AfternS: combined exercise session at the afternoon; MornS: combined exercise session at the morning; C: control session. \#p<.01 to AfternS vs. C; $\uparrow p<.05$ to MornS $v$. $\mathrm{C} ;{ }^{*} p<.05$ in relation to rest in the same session (AfternS); ${ }^{* *} p<.01$ in relation to rest in the same session (AfternS); $¥ p<.05$ in relation to rest in the same session (MornS). 
Figures 2 show values during 24h of ambulatory BP measurements in all experimental and control sessions. The SBP at 10 to 11 a.m. $(p<.01)$ and 4 to 5 p.m. $(p<.001)$ were lower in the AfternS sesson and MornS session, respectively, versus the $\mathrm{C}$ session. The DBP and MAP were lower in the MornS at 4 to 5 p.m. $(p<.027 ; p<.047)$, showing a hypotensive effect of experimental sessions versus the $\mathrm{C}$ session.

Post-exercise hypotension occurred following the experimental sessions for SBP in two periods, from 10 to 11 a.m. $(p<.03)$ and from 6 to 7 a.m. $(p<.006)$ for the AfternS; and for the MornS, in three periods, from 4 to 5 p.m. $(p<.045), 2$ to 3 a.m. $(p<.028), 6$ to 7 a.m. $(p<.041)$. For DBP, post-exercise hypotension occurred in two periods; for the AfternS from 4 to 5 a.m. $(p<.001)$ and 6 to 7 a.m. $(p<.043)$ and for the MornS from 2 to 3 a.m. $(p<.021), 6$ to 7 a.m. $(p<.016)$; and only MornS session in MAP from 2 to 3 a.m. $(p<.019)$ (Figure 2).

\section{Discussion}

The data from the present study are of clinical relevance, as the AfternS session resulted in lower SBP, DBP and MAP AUC values as compared with the day without exercise (C), during the sleeping hours. There was a similar response of DBP and MAP when MornS was compared with the $\mathrm{C}$ session. Confirming the initial hypothesis, these results revealed that the AfternS induced a higher decrease in nocturnal BP, which represents an important clinical application to cardiovascular prevention of an individual, and would allow for a lower BP reactivity while weakening.

Of note, lower values of BP during the morning may contribute to a decreased risk of stroke, ischemia, myocardium infarction and ventricular tachycardia (Gardner \& Schneider, 2001), which are more likely to occur during this period of the day (Jones, Pritchard, George, Edwards, \& Atkison, 2008; Paschos \& Fitzgerald, 2010; Stergiou et al., 2002). Nevertheless, there was a decrease of SBP AUC during sleeping and $24 \mathrm{~h}$ period following the MornS, which may prevent the increase of BP during stressful situations in daily living (Jones, Taylor, Lewis, George, \& Atikson., 2009; Jones et al., 2006).

However, independently from the period of the day (sleeping or during the day), a decrease in $\mathrm{BP}$ of $2 \mathrm{mmHg}$, may represent a decrease of $6 \%$ in stroke risk, and of $4 \%$ in chronic heart disease (Whelton, \& Appel, 2002). Additionally, Liu, Goodman, Nolan, Lacambe and Thomas (2012) found that an acute decrease of $\mathrm{BP}$ as consequence of exercise was correlated with the chronic decrease of BP in normotensive individuals, highlighting that even an acute decrease in BP has an impact on cardiovascular prevention.

Interestingly, Jiu-Jitsu is characterized to be an intense contact and grappling sport, where the main goal is to dominate the opponent by some techniques such as: projections, immobilizations, joint looks, twists and chokes. Impotantly, it has been shown that during neck chokes intra-ocular BP increases 10 $\mathrm{mmHg}$ in young Jiu-Jitsu athletes due to mechanical constriction of the neck (Scarpi et al., 2009). Moreover, during the fight there is a great need for isometric strength for the execution of some techiniques, which induces an increase in BP due to local vascular occlusion (Anthony et al., 2012). Nevertheless, the period of the day may impact BP elevations, as Stergiou et al. (2002) observed an increased risk of $12.7 \%$ in stroke during the morning (6 to 12 a.m.) and of $8 \%$ in the evening (4 to 8 p.m.), evidenced by an abrupt increase of SBP and DBP. However, in trained individuals the BP reactivity has been shown to be lower (Karabatakis et al., 2004; Natsis et al., 2009).

The combined exercise session used in the present study was effective in decreasing BP, which may provide cardiovascular protection. In practical terms, the decrease of BP during the morning following the afternoon exercise session may provide an additional cardiovascular protection, due to the higher rate of cardiovascular episodes observed during this period of the day.

Furthermore, combined training induces both cardiovascular and neuromuscular adaptations, which are important for Jiu Jitsu athletes, while isolated resistance or aerobic training would limit both adaptations (Kesse et al., 2011).

There is some evidence of the superiority of afternoon exercise in inducing post exercise hypotension as compared to morning exercise. Jones et al. (2008), investigated 440 individuals aged between 15 and 81 years submitted to a cycle ergometry aerobic exercise session. Results revealed that afternoon exercise induced higher drops in SBP, DBP and MAP compared with morning exercise. Jones et al.(2009), compared the effects of continuous versus interval cycle ergometry exercise performed during the morning and afternoon, and found that, regardless of the method used, SBP response was lower following the afternoon exercise.

Park, Jastremski and Wallace (2005), assessed 24h BP responses following treadmill walking at different times of the day in individuals classified as non-dippers and dippers, to that one's classified like dippers, case of the present sample. It was observed that exercise performed in the morning (6 to 8 a.m.) was more effective in decreasing SBP over $24 \mathrm{~h}$ $(-5.56 \pm 2.27 \mathrm{mmHg})$ versus when exercise was performed in the afternoon/evening ( 5 to 7 p.m.), in which was little change in $\operatorname{SBP}(0.11 \pm 2.29 \mathrm{mmHg})$.

The present study had some limitations: 1) reduced number of individuals and 2) the lack of $24 \mathrm{~h}$ measure during the $\mathrm{C}$ session in the morning. However, it's noteworthy that to our knowledge this is the first study that investigated the effects of a combined exercise session (aerobic + resistance) performed in different periods of the day (morning $v s$. afternoon) on the $\mathrm{BP}$ response, and to reduce this limitation, ambulatory measure of BP during the morning and afternoon at rest and up to 60 minutes following exercise (R15-R60) was performed, with no difference between these measures.

Finally, more studies using combined exercise during different periods of the day should be designed to investigate the potential different mechanisms involved in PEH. Different populations, especially individuals with higher cardiovascular risk should be studied.

\section{Conclusion}

The combined exercise performed at different periods of the day contributed distinctly to reductions in BP. The MornS 
was important in reducing SBP and MAP during the total-24h monitoring, and the AfternS in reducing SBP, DBP and MAP during sleeping hours in Jiu-Jitsu athletes. A combined exercise protocol, consisting of both resistance and aerobic exercise, modifies $24 \mathrm{~h}$ BP responses and may have great clinical relevance for Jiu-Jitsu athletes for cardiovascular health, especially in moments of daily life that increase psychosocial stress .

\section{References}

Andreato, L.V., Julio, U.F., Gonçalves Panissa, V L., Del Conti Esteves, J.V., Hardt, F., Franzói de Moraes, S.M., ...Franchini E. (2014). Brazilian jiu-jitsu simulated competition, Part II: Physical performance, time-motion, technical-tactical analyses and perceptual responses. Journal of Strength and Conditional Research. Dec 31. [Epub ahead of print].

Almeida, J., Campbell, C., Pardono, E., Sotero, R., Magalhães, G., \& Simões, H. (2010). Predictive equations validity in estimating the $\mathrm{VO}_{2}$ max of young Brazilians from performance in a $1600 \mathrm{~m}$ run. Revista Brasileira de Medicina do Esporte, 16, 57-60.

Anthony, W., Baross, J., Wiles, D.I., \& Swaine, L. (2012). Effects of the Intensity of Leg Isometric Training on the Vasculature of Trained and Untrained Limbs and Resting Blood Pressure in Middle-Aged Men. International Journal of Vascular Medicine Volume, Article ID 964697, 8 pages. doi:10.1155/2012/964697.

Borg, G.A.V. (2000). Escalas de Borg para a dor e esforço percebido. São Paulo: Manole.

Delpenho, B.P. (2009). Comparação da escala de omni-res com o protocolo de brzycki na predição de 1-rm em um exercício resistido. Universidade federal de juiz de fora faculdade de educação física e desportos.

Gardner, S.F., \& Schneider E.F. (2001). 24-hour ambulatory blood pressure monitoring in primary care. Journal of the American Board of Family Medicine, 14, 166-171.

Guimarães, J.I., Stein, R., Vilas-Boas, F., Galvão, F., Nóbrega, A.C.L., Castro, R.R.T., ...Brito, F. S. (2003). Normatização de técnicas e equipamentos para realização de exames em ergometria e ergoespirometria. Arquivos Brasileiros de Cardiologia, 80, 457-464.

Hecksteden, A., Grütters, T., \& Meyer, T. (2013). Association Between Postexercise Hypotension and Long-term Training-Induced Blood Pressure Reduction: A Pilot Study. Clinical Journal Sport Medicine, 23, 58-63.

Jackson A.S., \& Pollock M.L. (1978). Generalized equations for predicting body density of men. British Journal of Nutrition, 11, 497-504.

Jones, H., Pritchard, C., George, K., Edwards, B., \& Atkinson, G. (2008). The acute post-exercise response of blood pressure varies with time of day. European Journal of Applied Physiology, 104, 481-489.

Jones, H., Atkinson, G., Leary, A., George, K., Murphy, M., \& Waterhouse, J. (2006). Reactivity of Ambulatory Blood Pressure to Physical Activity Varies With Time of Day. Hypertension, 47, 778784; originally published online February 27. DOI: 10.1161/01. HYP.0000206421.09642.b5.

Jones, H., Taylor, C.E., Lewis, N.C.S., George, K., \& Atkinson, G. (2009). Post-exercise blood pressure reduction is greater following intermittent than continuous exercise and is influenced less by diurnal variation. Chronobiology International, 26, 293-306.

Karabatakis, V.E., Natsis, K.I., Chatzibalis, T.E., Lake, S.L., Bisbas, I.T., Kallinderis, K.A., \& Stangos, N.T. (2004). Correlating intraocular pressure, blood pressure, and heart rate changes after jogging. European Journal of Ophthalmology, 14, 117-122

Keese, F., Farinatti, P., Pescatello, L., Cunha, F.A., \& Monteiro, W.D. (2011). A comparison of the immediate effects of resistance, aerobic, and concurrent exercise on postexercise hypotension. Journal of Strength and Conditioning Research, 25, 1429-1436.

Keese, F., Farinatti, P., Pescatello, L., Cunha, F.A., \& Monteiro, W.D. (2012). Aerobic exercise intensity influences hypotension following concurrent exercise sessions. International Journal of Sports Medicine, 33, 148.

Liu, S., Goodman, J., Nolan, R., Lacombe, S., \& Thomas, S.G. (2012). Blood pressure responses to acute and chronic exercise are related in prehypertension. Medicine Science and Sports Exercise, 44, 1644-1652.

Medina, F.L., Lobo, F.S., Souza, D.R., Kanegusuku, H., \& Forjaz, C.L.M. (2010). Atividade física: impacto sobre a pressão arterial. Revista Brasileira de Hipertensão, 17,103-106.

Morais, P.K., Campbell, C.S.G., Sales, M.M., Motta, D.F., Moreira, S.R., Cunha, V.N.C., ...Simões, H. G. (2011). Acute resistance exercise is more effective than aerobic exercise for $24 \mathrm{~h}$ blood pressure control in type 2 diabetics. Diabetes \& Metabolism, 37, 112-117.

Moraes, M., Bacurau, R., Ramalho, J., Reis, F., Casarini, D., Chagas, J., ...Araujo, R.C. (2007). Increase in kinins on post-exercise hypotension in normotensive and hypertensive volunteers. Biological Chemistry, 388, 533-540.

Moreira, A., Franchini, E., De Freitas, C.S., Schultz, A.A.F., De Moura, N.R., Costa, E.C., \& Aoki, M.S. (2012). Salivary cortisol and immunoglobulin A responses to simulated and official Jiu-Jitsu matches. Journal of Strength and Conditional Research, 26, 2185-2191.

Motta, D., Lima, L., Arsa, G., Russo, P., Sales, M., \& Moreira, S.R.,... Campbell, C.S. (2010). Influence of type 2 diabetes on kallikrein activity after physical exercise and its relationship with post-exercise hypotension. Diabetes \& Metabolism, 36, 363-368.

Natsis, K., Asouhidou, I., Nousios, G,, Chatzibalis, T., Vlasis, K., \& Karabatakis, V. (2009). Aerobic exercise and intraocular pressure in normotensive and glaucoma patients. BMC Ophthalmology, 9, 6 doi:10.1186/1471-2415-9-6.

Paschos, G.K., \& FitzGerald, G.A. (2010). Circadian clocks and vascular function: Paschos Circadian clocks and vascular function. Circulation Research, 106, 833-841.

Park, S., Jastremski, C.A., \& Wallace, J.P. (2005). Time of day for exercise on blood pressure reduction in dipping and nondipping hypertension. Journal Human Hypertension, 19,597-605.

Queiroz, A.C.C., Kanegusuku, H., \& Forjaz, C.L.M. (2010). Efeitos do treinamento resistido sobre a Pressão Arterial de idosos. Arquivos Brasileiros de Cardiologia, 95, 135-140.

Rezk, C.C., Marrache, R.C.B., Tinucci, T., Mion, J.D., \& Forjaz, C.L.M. (2006). Post-resistance exercise hypotension, hemodynamics, and heart rate variability: inxuence of exercise intensity. European Journal of Applied Physiology, 98, 105112.

Ribeiro, F., Campbell, C.S.G., Mendes, G., Arsa, G., Moreira, S. R., Silva, F. M., \& ...Simões, H.G. (2011). Exercise lowers blood 
pressure in university professors during subsequent teaching and sleeping hours. International Journal of General Medicine, 4, 711-716.

Rodrigues, B.M., Sandy, D.D., Filho, M.L.M., Júnior, J.J.S., Venturini, G.R.O., \& Dantas, E.H.M. (2010). Sessão de treinamento resistido para membro superior com dois diferentes tempos de intervalo: efeitos na percepção subjetiva de esforço. Brazilian Journal of Biomotricity, 4, 131-139.

Sales, M.M., Russo, P.S., Moreira, S.R., Santana, H.A.P., Moraes, J.F., Asano, R.Y., ...Campbell, C.S.G. (2012). Resistance Exercise Elicits Acute Blood Pressure Reduction in Type-2 Diabetics. Journal of Exercise Physiology, 15, 98-109.

Santana, H.A.P., Moreira, S.R., Asano, R.Y., Sales, M.M., Córdova, C., Campbell, ... Simões, H.G. (2013) Exercise intensity modulates nitric oxide and blood pressure responses in hypertensive older women. Aging Clinical and Experimental Research, 25, 43-48.

Scarpi, M.J., Conte, M., Rossin, R.A., Skubs, R,, Lenk, R.E., \& Brant, R. (2009). Associação entre dois diferentes tipos de estrangulamento com a variação da pressão intraocular em atletas de jiu-jitsu. Arquivos Brasileiros de Oftalmologia, 72, 341-345.

Simões, G., Moreira, S., Kushnick, M., Simões, H., \& Campbell, C. (2010). Postresistance exercise blood pressure reduction is influenced by exercise intensity in type- 2 diabetic and nondiabetic individuals. Journal of Strength and Conditional Research, 24, $1277-1284$.

Siri, W.E. (1961). Body composition from fluid spaces and density. Analysis of methods. In: J. Brozek and A. Henschel (Eds), Techniques for Measuring Body Composition (p.223-44). National Academy of Sciences, National Research Council: Washington DC.

Sociedade Brasileira de Cardiologia, Sociedade Brasileira de Hipertensão; Sociedade Brasileira de Nefrologia. (2010). VI Diretrizes Brasileiras de Hipertensão. Arquivos Brasileiros de Cardiologia. 95.

Sotero, R.C., Pardono, E., Campbell, C.S.G., \& Simões, H.G. (2009). Indirect assessment of lactate minimum and maximal blood lactate steady state intensity for physically active individuals. Journal of Strength and Conditional Research, 23, 847-853.

Stergiou, G.S., \& Kostas, N., Vemmos, K.M., Pliarchopoulou, A.G., Synetos, L.G., Roussias, T. \& Mountokalakis, D. (2002). Parallel Morning and Evening Surge in Stroke Onset, Blood Pressure, and Physical activity. Stroke, 33, 1480-1486.
Tibana, R.A., Pereira, G.B., Navalta, J.W., Bottaro, M. \&, Prestes, J. (2013). Acute Effects of Resistance Exercise on 24-h Blood Pressure in Middle Aged Overweight and Obese Women. International Journal Sports Medine, 34, 460-464.

Whelton, P.K., He, J., Appel, L.J., Cutler, J.A., Havas, S., Kotchen, T.A., ...Karimbakas, J. (2002). Primary prevention of hypertension: clinical and public health advisory from The National High Blood Pressure Education Program. Journal of the American Medical Association, 288, 1882-1888.

\section{Authors' note}

Rafaello Pinheiro Mazzoccante, Ioranny Castro de Sousa, Jonato Prestes, Herbert Gustavo Simões, Carmen Sílvia Grubert Campbell are affiliated with the Graduate Program on Physical Education, Catholic University of Brasilia, Brazil.

Sérgio Rodrigues Moreira is affiliated with the College of Physical Education. Federal University of Vale do São Francisco. Petrolina/ PE, Brazil.

\section{Corresponding author}

Rafaello Pinheiro Mazzoccante

Programa de Mestrado e Doutorado em Educação Física da Universidade Católica de Brasília, Águas Claras, Taguatinga-DF, 72022-900, Brasil. EPTC, QS07, LT1. Bloco G Sala 001 Águas Claras - Brasília DF - Brasil

Telefone: +55 (61) 33569698

Email: rafa_mazzoccante@hotmail.com

Manuscript received on August 23, 2014

Manuscript accepted on May 26, 2015

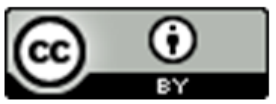

Motriz. The Journal of Physical Education. UNESP. Rio Claro, SP, Brazil - eISSN: 1980-6574 - under a license Creative Commons - Version 3.0 